\title{
Type 1 Ig-E mediated allergy to human insulin, insulin analogues and beta-lactam antibiotics
}

Hipersensibilidade imediata a insulina humana, análogos de insulina e a antibióticos beta-lactâmicos

\author{
Pedro Andrade ${ }^{1}$ \\ Margarida Gonçalo ${ }^{3}$
}

\author{
Luísa Barros
}

\begin{abstract}
Insulin, a crucial therapeutic agent for diabetes mellitus, has been rarely associated with hypersensitivity events. We present a 69-year-old type-2 diabetic patient with urticariform lesions on the sites of subcutaneous injection of insulin. The patient denied any known allergies, except for an unspecific cutaneous reaction after intramuscular penicillin administration in childhood. Prick tests revealed positive reactions to all tested human insulins and insulin analogues. Serum IgE levels were above normal range and RAST tests were positive for human, bovine and porcine insulins, as well as beta-lactams. Type 1 IgEmediated allergy to insulin analogues demands a prompt diagnosis and represents a significant therapeutic challenge in diabetic patients.

Keywords: Diabetes mellitus, type 2; Drug hypersensitivity; Insulin; Penicillins

Resumo: A insulina é um agente indispensável para o controlo da diabetes mellitus. Os efeitos adversos da sua administração, em particular fenómenos de hipersensibilidade, são raros. Apresentamos um doente de 69 anos, diabético do tipo 2, com episódios recorrentes de lesões urticariformes nos locais de administração subcutânea de insulina. Negava alergias medicamentosas, à excepção de reacção não especificada na infância após penicilina intramuscular. Foram realizados testes cutâneos por puntura (prick tests) com diversos tipos de insulina humana e análogos, todos com reacções positivas, associando elevação dos níveis de IgE sérica e provas RAST positivas para as insulinas humana, bovina e porcina e para os antibióticos beta-lactâmicos. A alergia a análogos de insulina exige um diagnóstico precoce, originando um desafio terapêutico importante no doente diabético.

Palavras-chave: Diabetes mellitus tipo 2; Hipersensibilidade a drogas; Insulina; Penicilinas
\end{abstract}

Received on 05.08 .2011

Approved by the Advisory Board and accepted for publication on 08.11.2011.

* Study carried out at the Dermatology and Venereology Service, Teaching Hospitals of University of Coimbra (Universidade de Coimbra, EPE) - Coimbra, Portugal

Financial Support: None.

Conflict of Interests: None.

M.D. - Intern of Dermatology and Venereology - Dermatology and Venereology Service, Teaching Hospitals of University of Coimbra (Universidade de Coimbra, EPE) - Coimbra, Portugal.

M.D. - Specialist in Endocrinology - Hospital Assistant - Endocrinology Service, Teaching Hospitals of University of Coimbra (Universidade de Coimbra, EPE) - Coimbra, Portugal.

M.D. - Specialist in Dermatology and Venereology - Service Head - Dermatology and Venereology Service, Teaching Hospitals of University of Coimbra (Universidade de Coimbra, EPE) - Coimbra, Portugal.

(C)2012 by Anais Brasileiros de Dermatologia 


\section{INTRODUCTION}

Insulin is an essential therapeutic agent for the management of diabetes mellitus. Immediate hypersensitivity to recombinant human insulin preparations and insulin analogues is rare and may be associated with hypersensitivity to other molecules.

\section{CASE REPORT}

We present the case of a 69-year-old male with type 2 diabetes mellitus diagnosed at the age of 63 , that due to insufficient glycemic control on oral therapy alone and intolerance to some oral antidiabetics, was treated with premixed insulin analogues lispro and lispro protamine (Humalog Mix $25^{\mathrm{TM}}$ ) during the previous two years. The onset of pruriginous urticariform abdominal plaques with peripheral pale halos was observed, arising within minutes at the sites of subcutaneous insulin administration and occasionally at distant sites, recurring at nearly every insulin injection in the past year (Figure 1). Lesions regressed spontaneously in the space of a few minutes or hours. Glycemic control was acceptable (serum glycated hemoglobin $A_{1}$ c levels were $53 \mathrm{mmol} / \mathrm{mol}-7.0 \%$ - at presentation) and apparently unaffected by the cutaneous reaction.

The patient presented class I obesity (body mass index 31), dyslipidemia and arterial hypertension and was regularly treated with oral atorvastatin $20 \mathrm{mg}$ o.d., telmisartan $80 \mathrm{mg}$ o.d., hydrochlorothyazide $12.5 \mathrm{mg}$ o.d. and triflusal $300 \mathrm{mg}$ o.d.. No known allergies were reported, apart from a generalized erythematous cutaneous eruption of unclear nature following intramuscular penicillin injection in his childhood, which justified the avoidance of beta-lactam antibiotics ever since.

The diagnosis of immediate hypersensitivity to insulin analogue lispro was therefore suspected. Rechallenging administration of $2 \mathrm{U}$ of the regularly used insulin induced, in few minutes, a new pruriginous urticariform lesion at the site of the injection (Figure 2).

Prick tests using several different types of human insulin and insulin analogues were performed and all of them triggered positive reactions (papule diameters $>3 \mathrm{~mm}$ after 20 minutes and $>5 \mathrm{~mm}$ after 60 minutes) (Table 1). Papules 5 and $7 \mathrm{~mm}$ in diameter were observed 20 and 60 minutes after prick test with Merck ${ }^{\circledR}$ histamine $10 \mathrm{mg} / \mathrm{ml}$ solution (positive control), while no reaction was induced by isotonic sodium chloride solution (negative control).

Total serum IgE was three times above the normal limit $(312 \mathrm{UI} / \mathrm{ml})$, with class 3 radioallergosorbent tests (RAST) for human, bovine and porcine insulins $(13.2 \mathrm{KU} / \mathrm{L}, 16.0 \mathrm{KU} / \mathrm{L}$ and $14.3 \mathrm{KU} / \mathrm{L}$ respectively). Interestingly, RAST for beta-lactam antibiotics were reported as Class $2(1.0 \mathrm{KU} / \mathrm{L}$ for penicillin $\mathrm{G}, 0.94 \mathrm{KU} / \mathrm{L}$ for penicillin $\mathrm{V}, 0.87 \mathrm{KU} / \mathrm{L}$ for ampicillin and $0.72 \mathrm{KU} / \mathrm{L}$ for amoxycillin), and Class 0 for cefaclor $(0.08 \mathrm{KU} / \mathrm{L})$.

These results allowed the confirmation of type 1 IgE-mediated hypersensitivity to human insulin and insulin analogues lispro, glargine and detemir. In addition, despite being insufficient for clear identification of hypersensitivity to beta-lactams, results concerning these antibiotics were considered relevant, based on the previous cutaneous eruption following penicillin treatment and the age of the patient, which in association with the lack of re-exposure to beta-lactams during several decades might explain the low serum concentration of specific IgE. Even so, it is interesting to notice the absence of cross-reactivity with cephalosporin.

After evaluation by an endocrinologist, insulin therapy was suspended and the patient began the intake of an oral anti-diabetic drug association. Cutaneous lesions did not recur and reasonable glyce-

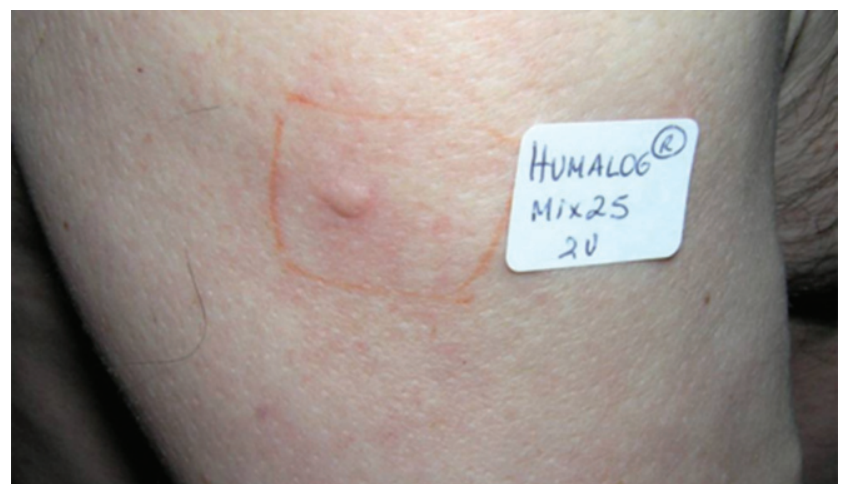

FIGURE 2: Pruriginous papule with $7 \mathrm{~mm}$ in diameter arising 20 minutes after rechallenging $2 \mathrm{U}$ of Humalog Mix $25^{\mathrm{TM}}$ in the right arm 
mic control was achieved after three months (fasting blood glucose levels ranging between 5,5$11.0 \mathrm{mmol} / \mathrm{L}$; serum glycated hemoglobin $55 \mathrm{mmol} / \mathrm{mol}-7.2 \%)$. As a high risk diabetic patient with several associated vascular and metabolic comorbidities, oral therapy has been considered insufficient and the patient has been proposed for insulin desensitization.

TABLE 1: Prick tests with different human insulins and insulin analogues. NC: not considered due to local scratching

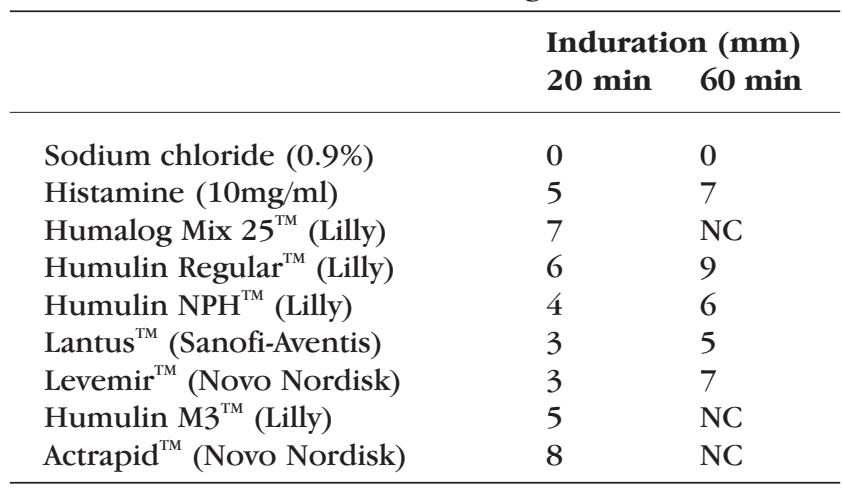

\section{REFERENCES}

1. Pereira LC. Urticaria medicamentosa. An Bras Dermatol. 1968;43:267-71

2. Heinzerling L, Raile K, Rochlitz H, Zuberbier T, Worm M. Insulin allergy: clinical manifestations and management strategies. Allergy. 2008;63:148-55

3. Wessbecher R, Kiehn M, Stoffel E, Moll I. Management of insulin allergy. Allergy. 2001; $56: 919-20$

4. Scheer BG, Sitz KV. Suspected insulin anaphylaxis and literature review. J Ark Med Soc. 2001;97:311-3

5. Pföhler C, Müller CS, Hasselmann DO, Tilgen W. Successful desensitization with human insulin in a patient with an insulin allergy and hypersensitivity to protamine: a case report. J Med Case Reports. 2008;2:283

6. Barranco R, Herrero T, Tornero P, Barrio M, Frutos C, Rodríguez A, et al. Systemic allergic reaction by a human insulin analog. Allergy. 2003;58:536-7

7. Durand-Gonzalez KN, Guillausseau N, Pecquet C, Gayno JP. Glargine insulin is not an alternative in insulin allergy. Diabetes Care. 2003;36:2216.

8. Caruso C, Alonzi C, Gaeta F, Viola M, Romano A. Same-patient allergy to ampicillin and human insulin. Allergy. 2009;64:1105-7.

9. Jegasothy BV. Allergic reactions to insulin. Int J Dermatol. 1980;19:139-41.

\section{DISCUSSION}

Urticaria may, in some cases, be triggered by drugs. ${ }^{1}$ Immediate hypersensitivity to insulin is a rare condition among patients suffering from type 2 diabetes mellitus, particularly after the development of recombinant human insulins, which are clearly less immunogenic than former animal preparations. ${ }^{2}$ In most cases it presents as immediate urticariform lesions or pruritus on the sites of the triggering injection, and in some instances also on other recent administration sites. ${ }^{3}$ Due to the risk of serious reactions such as angioedema, anaphylactic shock and glycemic control deterioration, suspicion of insulin hypersensitivity should lead to therapy suspension and diagnosis confirmation by complete immunologic work-up. ${ }^{4}$ Management of these patients might be challenging and should involve a multidisciplinary team. Rarely, additives such as meta-cresol, zinc or protamine, included in commercial insulin preparations, may be the responsible allergens, and this possibility was not excluded in the present case. ${ }^{5}$

Insulin analogues have been considered as useful alternatives for insulin hypersensitivity patients, despite some rare demonstrations of their immunogenicity. ${ }^{2,6,7}$ The present case corroborates the allergenic potential of short-acting and long-acting insulin analogues. The associated hypersensitivity to beta-lactam antibiotics is also noteworthy and has been previously reported in few cases of type 1 IgE-mediated insulin allergy. ${ }^{2,8,9} \square$

\author{
MAILING ADDRESS: \\ Pedro Andrade \\ Serviço de Dermatologia e Venereologia - \\ Hospitais da Universidade de Coimbra \\ Praceta Mota Pinto \\ 3000-075 Coimbra - Portugal \\ E-mail: pedro.andrade@portugalmail.com
}

How to cite this article: Andrade P, Barros L, Gonçalo M. Type 1 Ig-E mediated allergy to human insulin, insulin analogues and beta-lactam antibiotics. An Bras Dermatol. 2012;87(6):917-9. 